\title{
Bureaucratic Factors Impeding the Delivery of Infrastructure at the Metropolitan Municipal and District Assemblies (MMDAs) in Ghana
}

\author{
Joe Kingsley Hackman, Joshua Ayarkwa, Dickson Osei-Asibey, \\ Alex Acheampong, Prince Asher Nkrumah* \\ Department of Construction Technology and Management, Kwame Nkrumah University of Science and Technology (KNUST), \\ Kumasi, Ghana \\ Email: kohackman1@gmail.com, ayarkwajosh@yahoo.com, dicksonoseiasibey@gmail.com, \\ achielex@gmail.com, ^pankrumahknust@gmail.com
}

How to cite this paper: Hackman, J.K., Ayarkwa, J., Osei-Asibey, D., Acheampong, A. and Nkrumah, P.A. (2021) Bureaucratic Factors Impeding the Delivery of Infrastructure at the Metropolitan Municipal and District Assemblies (MMDAs) in Ghana. World Journal of Engineering and Technology, 9, 482-502.

https://doi.org/10.4236/wjet.2021.93032

Received: May 7, 2021

Accepted: July 25, 2021

Published: July 28, 2021

Copyright $\odot 2021$ by author(s) and Scientific Research Publishing Inc. This work is licensed under the Creative Commons Attribution International License (CC BY 4.0).

http://creativecommons.org/licenses/by/4.0/

(c) (i) Open Access

\begin{abstract}
Decentralisation of infrastructure delivery to sub-national governments has become commonplace in governments worldwide especially in developing countries such as Ghana. This is due to the benefits of decentralisation in improving public service delivery. However, decentralised infrastructure delivery is marred with numerous challenges that render most local governments incapable of providing infrastructure within their localities. This paper explored the bureaucratic factors that impede infrastructure delivery at the MMDAs in Ghana. A questionnaire survey with 121 construction professionals in the Departments of Works (DoWs) of the MMDAs within the Ashanti and Greater Accra Regions of Ghana was conducted. The results indicated six (6) major components of the bureaucratic factors that impede the delivery of infrastructure at the MMDAs: Central government bureaucracy; Minimal control of MMDAs; Political influence; MMDA project funding; Lack of capacity of MMDAs; and Political interference. This paper calls for a more committed central government to the establishment of adequate decentralised structures and implementation of major reforms that would remove the bureaucratic obstacles in the delivery of infrastructure at the MMDAs, to ensure effective infrastructure delivery at the MMDAs.
\end{abstract}

\section{Keywords}

Bureaucratic, Factors, Decentralisation, Infrastructure Delivery, District Assemblies

\section{Introduction}

Decentralisation has been regarded as the major institutional framework for eco- 
nomic growth and development in the last decades around the world [1] [2]. A major significance of decentralisation is the enhancement of the generation of revenue at the local level, provision of infrastructure, and ensuring the adequacy of resources provided to the local government. Experts in decentralisation believe that local governments can aid in the provision of infrastructure and reduction of poverty if they are provided with adequate resources. Decentralisation is aimed at re-structuring the systems of government in a manner in which it can satisfactorily provide services to the populace. Decentralisation of infrastructure delivery to sub-national governments has hence become a worldwide trend for governments, especially in developing countries like Ghana [3]. This is because the quantity and quality of infrastructure needed to propel rapid economic development are absent in most developing African countries [4]. Organisation for Economic Co-operation and Development/African Center for Economic Transformation (OECD/ACET) [5] asserted that African countries lag behind in terms of infrastructure development due to unclear infrastructure policy frameworks. In analyzing the concept of decentralised infrastructure and local governance, several major issues continuously show up [6]. Decentralisation of infrastructure delivery at the local government levels is faced with numerous challenges that cripple the efforts of local governments in their delivery of infrastructure [7].

In Ghana, the central government controls most of the activities to be undertaken by the local governments (i.e. the MMDAs), almost rendering them inefficient [8]. The practice of decentralisation requires that the MMDAs carry out some of the responsibilities which hitherto were being performed by the central government [9]. Hence, the MMDAs in Ghana are tasked with the responsibilities of providing administrative, fiscal, social services and amenities to their communities. However, most of these MMDAs are under excessive bureaucratic control from the central government (i.e. National, Regional, Political, Administrative and Technical control, etc.) [10]. Bureaucratic control of the MMDAs by central government agencies is, therefore, a predominant challenge affecting decentralised infrastructure delivery in Ghana. For instance, most of the decisions, including rules and regulations, are made solely by the central authorities. According to Ringo and Mollel [11], local governments are unable to make important decisions independently because many legal provisions make them dependent on the central government. The MMDAs in Ghana are not allowed to take centre stage in most infrastructure projects delivery decisions including the autonomy to recruit their staff or cater for their staffing needs. Also, with regards to the selection of contractors to undertake infrastructure projects at the local level, the MMDAs often have little roles to play in that [12]. Most of these contractors are selected on a political basis [13] [14] and this renders the MMDAs no choice but to work with these contractors even if they are not competent enough to execute the works, thereby affecting the delivery of quality infrastructure [15]. Ngware and Haule [16] asserted that for local governments to be able 
to thrive in sustainable grassroots social development, they must have the unregulated power to serve the local people rather than act as agents for the central government. Again, decentralisation reforms in Ghana lag behind most of its competitors due to lack of commitment and stringent bureaucratic interference from Central Government agencies [17]. These agencies are not fully committed to the implementation of major reforms to ensure effective delivery of infrastructure at the MMDAs. Gaining the support and commitment of central government officials for decentralisation is very critical. Decentralisation of infrastructure can be improved by limiting the interference of the central government in the operations of the MMDAs including the delivery of infrastructure. Although the central government needs to maintain sufficient control over the MMDAs, these controls should not, in any way, interfere with their task of delivering infrastructure.

The unwillingness of the central government to relinquish or share power has been a major impediment to effective decentralisation in the country [18]. Politicians have, more often than not, used the slogan of decentralisation as rhetoric to strengthen their power base rather than improving the quality of governance in the government [19]. Although decentralisation brought some positive results in some countries, in most parts it had yielded modest or low results. The sought powers and autonomy which decentralisation processes are keen to distribute downward are significantly held by central authorities [11]. According to Olaseni and Alade [4], the Public Procurement Act of Ghana, 2003 (Act 663) and the Amendment Act, 2016 (Act 914) being the main legal requirement for ensuring transparency in public infrastructure delivery, hardly achieve value for money construction projects to the Ghanaian taxpayer; and have been subjected to abuse due to bureaucratic controls from central government agencies [20]. The bureaucratic challenges faced by the MMDAs in Ghana hamper their ability to effectively deliver decentralised infrastructure. Therefore, this paper had the objective of assessing the bureaucratic factors that impede the delivery of infrastructure at the MMDAs in Ghana with the view to improving infrastructure development in Ghana, particularly at the local level.

\section{Review of Related Previous Research}

Decentralisation of infrastructure delivery has been one of the prime mandates of governments all over the world, and Ghana is no exception. Infrastructure which includes roads, power, water, sanitation, and airports, among others are the fundamental prerequisite for economic growth and development [21]. The provision of adequate infrastructure is essential for sustained and inclusive growth. Studies across the world have consistently shown the close relationship between decentralised infrastructure and the strength of economic output [22]. However, the effectiveness of delivering decentralised infrastructure projects has been adversely impacted by excessive bureaucracy in public procurement [23]. There are various definitions of the term "bureaucracy"; but, historically, the first to use 
and describe it was Max Weber. He believed bureaucracy was the most efficient way to set up an organisation or administration. Karimi et al. [23] p. 67 defined bureaucracy as "the administrative structure and set of regulations in place to control (rationalize, render effective and professionalize) activities, usually in large organisations and government". The benefits of bureaucracy include enhanced efficiency, logic, and rationality in organisations [24]. However, it tends to lead to inflexibility and rigidity, which hampers decision-making and creates a general inability to respond to rapid changes or crises [25]. Bureaucracy creates the centralisation of power, authority, and responsibilities, thereby resulting in delays and inefficiencies of local governments in delivering infrastructure [23]. Many local governments in developing countries in Africa have been unable to provide huge urban infrastructure in the face of challenges such as inadequate logistics to support effective revenue mobilization, low rates of tax collection, under-declaring of revenues by revenue collectors, political interference, and corruption, among many others [26] [27] [28], which can be associated with excessive bureaucracy.

Several bureaucratic factors hinder the efforts of the MMDAs in the delivery of infrastructure. In Ghana, lack of funding is often cited as the biggest impediment to decentralised infrastructure delivery in Ghana [29]. Most local governments in developing countries lack the financial capacity to do the job [30]. This creates difficulties on the part of the MMDAs in executing infrastructure delivery and causes many projects to be left hanging. However, a recent study by Martin Williams of the London School of Economics, supported by the International Growth Centre (IGC), suggests that a bigger constraint to infrastructure delivery in Ghana may be from the institutional management of such projects [29]. Hence, infrastructure delivery at the local level often requires the establishment of an efficient institutional framework to ensure effective implementation [31]. Moreover, Kissi et al. [13] opined that there is growing concern over the unsuccessful delivery of infrastructural projects in various Works Departments at the MMDAs in Ghana. There exists inefficient delivery of infrastructure at the MMDAs, and this has led to low confidence in local government authorities in terms of the delivery of decentralised infrastructure. An important avenue for improving infrastructure delivery, therefore, lies in rationalising the institutional mechanisms which underpin the funding sources and ensuring that MMDAs complete existing projects before starting new ones [29]. Togba [32] asserted that constraints such as limited resources, weak institutional capacity, inadequate mechanisms of accounting and accountability, and limited availability of information are major challenges to the delivery of infrastructure at the local level. Weak institutional capacity is one of the major challenges debilitating against the effective delivery of infrastructure by the MMDAs [33].

The greatest challenge to local government's delivery of infrastructure has been the lack of political commitment of the central government to decentralize infrastructure [18]. Bhattacharya et al. [34] highlighted that infrastructure being 
long term requires large upfront investments, and generates cash flows only after many years. Most present governments reject the policies of the previous government and set new ones, reshuffle the DoWs making the delivery of infrastructure at the MMDAs difficult. Infrastructure delivery at the MMDAs requires a strong political will and commitment of central government agencies for the implementation of major reforms to ensure effective infrastructure delivery at the MMDAs [17].

Political influence is another significant bureaucratic factor that impedes the effective delivery of infrastructure at the MMDAs [14] [35]. There are often attempts made by political leaders to influence the procurement processes where they bring in party-faithful for the award of contracts [13]. Most often the contractors brought in are not competent enough to execute the works resulting in the poor delivery of infrastructure. According to Asante [36] p. 70, "In many areas of business, success comes down to who you know rather than what you know. This is especially true of government contracts where political affiliations can make all the difference in securing a contract. Political pressures influence contract decisions such as awarding many contracts to a particular contractor at a time; not based on competition and also awarding contracts without making budget allocations". Other cases of political influences can be identified where when there is a change in government (i.e. change in the political party that rules the country), projects are given to new contractors who are political party affiliates, as well as the abandonment of started projects by previous governments to commence new ones. A study conducted by Damoah et al. [37] suggests that government deliberately abandon projects and then re-award them to their party members. Changes in government always leave most government agencies like MMDAs in dilemma and almost not knowing what to do during the first year of the new government, especially where the new government is from a different political party.

According to Bertucci [38], poor coordination within local governments adversely affects their infrastructure delivery capacity. Problems with coordination may occur as per the organogram of the MMDAs. A serious problem that has arisen is that of horizontal and vertical coordination between agencies belonging to different levels of government [14]. This has created problems of duplication or gaps in the provision of synergy in the utilisation of resources. Poor coordination between different stages and types of government, long delays in permit issuance, and major difficulties with land acquisition have led to major delays for even those projects where funding was available. This often discourages private investors from participating in public-private partnerships [39]. These coordination problems are particularly serious in schemes for drinking water and sanitation, irrigation, roads, etc., where the financial requirements and technical complexity require involvement by higher levels of government [39]. Furthermore, one of the major problems faced by the MMDAs is the central control of infrastructure procurement [8]. This is a situation where the procurement of infra- 
structural works at the local level is massively controlled by central authorities resulting in delays in major construction projects. Infrastructure procurement at the MMDAs is usually embedded in lots of bureaucracy requiring extensive authorisation procedures thereby, making procurement a tedious, laborious and slow process [35] [40].

\section{Methodology}

To explore the bureaucratic factors that impede the delivery of infrastructure at the MMDAs in Ghana, the research followed the quantitative approach and surveyed with structured questionnaires. This agrees with Creswell [41] who asserted that the quantitative approach to research allows for the use of structured questionnaire surveys and enables researchers to generalise their findings from a sample of the population. The quantitative research approach is appropriate for a research where the researcher has some information of his population. Questionnaire survey also helps to provide trends in the population [42]. The questionnaire consisted of two parts namely demographic or background information of the respondents, and bureaucratic factors that impede the delivery of infrastructure at the MMDAs in Ghana. The first part comprised the job position, academic qualification, and resident District Assembly (DA) of respondents as well as their years of working experience in the MMDAs. DAs connote the Metropolitan Municipal and District Assemblies as interpreted by Section 234 of the Local Governance Act, 2016 (Act 936). The second part had 22 factors that were obtained from an extensive review of extant literature. The questionnaires were distributed to construction professionals in the Department of Works (DoWs) of the various MMDAs in the Ashanti and Greater Accra Regions of Ghana. The Greater Accra and Ashanti Regions of Ghana are viewed as the most urbanised, populated, and rapidly growing regions in Ghana, and hence, almost all infrastructure developmental activities are focused in these two regions [43]. The selection of the Greater Accra and Ashanti Regions of Ghana as units of analysis for the study was therefore appropriate since the DoWs of the MMDAs within these regions are usually engaged with a lot of infrastructure projects and are endowed with construction professionals with enough practical experience in infrastructure delivery. According to the Works Departments Operational Manual [44], the DoWs are the bodies under the DAs that ensure the effective implementation of infrastructural works (building, water, and feeder roads) related policies and programmes at the local level. The study considered all three (3) Metropolitan Assemblies in the two (2) Regions and employed a simple ratio sampling approach to select Municipal and District Assemblies from the remaining Municipal and District Assemblies in alphabetical order. By employing the simple ratio approach, two (2) was chosen as the common multiple for the selection. Hence, every $2^{\text {nd }}, 4^{\text {th }}, 6^{\text {th }}$, etc. within the Municipal Assemblies and District Assemblies were selected. In all, a total of 36 MMDAs were obtained representing 3 Metropolitan Assemblies, 19 Municipal Assemblies, and 14 Dis- 
trict Assemblies. Out of this, a total of 150 construction professionals were purposively sampled and were required to respond to the questionnaires. Considering the limited number of construction professionals in each DoWs of the MMDAs in Ghana, this number of professionals sampled is considered adequate for the study. Purposive sampling involves the use of the researcher's discretion to select a sample which per his understanding possesses the knowledge and expertise needed to provide the requisite information for the study [45]. The data collected was encoded using the Statistical Package for Social Sciences (SPSS) Version 23. The results were carefully analysed statistically using descriptive statistics (frequencies and mean score) and principal component analysis. Kendall's Coefficient of Concordance was used to ascertain the level of agreement between the variables.

\section{Results and Discussion}

The results and discussion of both the demographic or background data of the respondents and the data relating to the objectives of the study are presented below. The data gathered from the construction professionals in the DoWs across the selected MMDAs in the Ashanti and Greater Accra Regions of Ghana were analysed and discussed. Out of a total number of 150 questionnaires administered to the respondents, 121 were retrieved, representing a response rate of 81 per cent, which were used for the analysis. In any research, a return of more than 50 per cent is acceptable and reliable [9].

\subsection{Demographic Characteristics of the Respondents}

The descriptive statistics of the demographics were studied to enable the researcher to evaluate the respondent's characteristics relevant to the study. This was done to enhance the understanding of the participants' profile and increase the degree of confidence in the data reliability and precision. According to Ahadzie [46], the background information of respondents is required to authenticate the credibility of the data gathered. The aim of presenting the background data of respondents who take part in a study is to enhance the confidence in the reliability of the data collected [47]. The questionnaires covered the job position or title of respondents, academic qualification, and the number of years spent in the MMDAs. Regarding the job position or title of the respondents, 28 per cent of them were Engineers, 26 per cent were Technical Officers, 17 per cent were Architects, 12 percent each were Quantity Surveyors and Heads of Departments, 3 per cent were Project Managers, whiles 2 per cent of the respondents were Estate Managers. When asked about their academic qualification, the majority (41 per cent) had an undergraduate degree, 37 per cent of the respondents had a master's degree, and the remaining (22 per cent) had either HND or City and Guilds Certificates. Also, regarding the number of years spent in the MMDAs, 34 per cent of the respondents surveyed had more than 5 years' experience in the various MMDAs, 30 per cent had 3 - 5 years' working experience, whiles a total of 30 
per cent of the respondents had 1 - 2 years' working experience in the various MMDAs. Only 7 per cent had less than 1-year of working experience in the MMDAs. This indicates that the respondents have enough experience in construction and as such the information obtained from them can be regarded as credible and reliable.

\subsection{Bureaucratic Factors That Impede the Delivery of Infrastructure at the MMDAs}

The study aimed to explore the bureaucratic factors that impede the delivery of infrastructure at the MMDAs. For this purpose, mean scores and principal component analysis were employed to analyse the quantitative data collected.

\subsubsection{Mean Score Ranking}

According to Cheng and $\mathrm{Li}$ [48], the mean score ranking technique is used to test the significance of factors. A Likert scale of $1-5(1=$ least important and $5=$ most important) was used in the questionnaires to aid the respondents in rating their level of agreement to the 22 bureaucratic barriers identified. Mean scores were used to rank the bureaucratic factors that impede the delivery of infrastructure at the MMDAs. Factors with the lowest standard deviation are given the highest rank in situations where two or more factors have the same mean score [49]. Table 1 shows the mean scores, standard deviation, and ranks of the bureaucratic barriers. The mean score ranking of the bureaucratic barriers was followed by principal component analysis.

From Table 1, slow implementation of decentralisation reforms by the central government was ranked 1st with a mean of 3.12. Line ministries' resistance to decentralisation was ranked 2nd with a mean of 2.95. Both the 6th and 7th factors had equal mean values. In such circumstances, the factor with the lowest standard deviation is ranked higher and the factor with the higher standard deviation is ranked lower.

To properly offer a descriptive analysis of these values in Table 1 , it is imperative to determine a theoretical mean for the analysis. The theoretical mean is defined as the mean for the possible sample means obtained and is sometimes termed as the population mean [50]. From the study it can be calculated as:

$$
\mu \pi=\sum \pi / n
$$

where; $\sum \pi=$ the sum of all the means obtained for each variable;

$n=$ the total number of variables.

The theoretical mean for the analysis was determined as:

$$
\begin{gathered}
\mu \pi=58.83 / 22 ; \\
\mu \pi=2.67 .
\end{gathered}
$$

Hence, the theoretical mean was found to be 2.67. As such, all mean scores that fell below this mean were deemed not important and vice versa. Hence, for a scale of $1-5$, a mean of 2.67 or more means the factor is important. The mean scores for the factors ranged between 3.12 for the highest to 2.29 for the lowest. 
Table 1. Mean score ranking of bureaucratic barriers.

\begin{tabular}{|c|c|c|c|c|}
\hline S/N & Bureaucratic Barriers & Mean & SD & Rank \\
\hline 1 & Slow implementation of decentralisation reforms & 3.12 & 1.106 & 1 \\
\hline 2 & Line ministries' resistance to decentralisation & 2.95 & 1.104 & 2 \\
\hline 3 & Regional controls & 2.89 & 0.928 & 3 \\
\hline 4 & Manipulation of stakeholders & 2.87 & 1.089 & 4 \\
\hline 5 & $\begin{array}{l}\text { Use of inefficient political contractors for } \\
\text { infrastructure project delivery }\end{array}$ & 2.82 & 1.112 & 5 \\
\hline 6 & Corruption in infrastructure procurement & 2.80 & 0.898 & 6 \\
\hline 7 & Control of appointments/promotions at the MMDAs & 2.80 & 0.944 & 7 \\
\hline 8 & Political elite influence & 2.74 & 1.116 & 8 \\
\hline 9 & Project location selection & 2.72 & 1.033 & 9 \\
\hline 10 & Regime change & 2.70 & 1.03 & 10 \\
\hline 11 & Slow disbursement of project funding & 2.69 & 1.072 & 11 \\
\hline 12 & $\begin{array}{l}\text { Central control of infrastructure procurement delaying construction } \\
\text { projects }\end{array}$ & 2.68 & 0.769 & 12 \\
\hline 13 & Interference with legal mandate of MMDAs by MDAs & 2.62 & 0.844 & 13 \\
\hline 14 & Imposition of decisions & 2.61 & 1.059 & 14 \\
\hline 15 & Inadequate project financing & 2.60 & 0.76 & 15 \\
\hline 16 & Lack of stakeholders' consultation on infrastructure delivery policies & 2.53 & 0.891 & 16 \\
\hline 17 & Lack of political commitment to decentralised infrastructure delivery & 2.52 & 0.711 & 17 \\
\hline 18 & Poor coordination within the MMDAs & 2.50 & 0.78 & 18 \\
\hline 19 & Complicated system of financial transfers to local governments & 2.48 & 0.769 & 19 \\
\hline 20 & Lack of transparency in infrastructure project selection & 2.47 & 0.881 & 20 \\
\hline 21 & Lack of involvement of MMDAs in project selection & 2.43 & 1.109 & 21 \\
\hline 22 & Inadequate control on tax bases for infrastructure delivery & 2.29 & 0.847 & 22 \\
\hline
\end{tabular}

Out of the 22 bureaucratic factors, 12 factors had their mean values greater than 2.67 namely: Slow implementation of decentralisation reforms by the central government; Line ministries' resistance to decentralisation; Regional controls; Manipulation of stakeholders; Use of inefficient political contractors for infrastructural project delivery; Corruption in infrastructure procurement; Control of appointments/promotions at the MMDAs; Political elite influence; Project location selection; Regime change; Slow disbursement of project funding; and Central control of infrastructure procurement delaying construction projects, and hence were deemed important.

\subsubsection{Kendall's Coefficient of Concordance}

In ascertaining the overall agreement amongst sets of ranking, Kendall's Coefficient of concordance was used. Kendall's Coefficient of Concordance test was used to confirm the reliability of the five-point scales by measuring the internal 
consistency among the various factors. For Kendall's W, "no agreement" and "complete agreement" are represented by the values 0 and +1 respectively, from a range 0 to +1 . The Kendall's $W$ value for bureaucratic barriers was 0.035 as shown in Table 2. This means that the five-point scale used was reliable and the factors that were measured had internal consistency.

\subsubsection{Principal Component Analysis}

The study employed principal component analysis to reveal the key or principal significance barriers from the large set of 22 bureaucratic factors. This was achieved by grouping the bureaucratic barriers into broad categories. Principal component analysis was more appropriate because the variables were many [51]. The suitability of the principal component analysis was tested using the Kaiser-Meyer-Olkin (KMO) measure of adequacy and Bartlett's test sphericity. From the data analysis, the KMO test was 0.753 (Table 3), suggesting that the data set was appropriate as they have exceeded the recommended threshold of 0.5 [52], and good as the KMO ranged between 0.7 and 0.8 [51].

From the principal component analysis, six (6) bureaucratic barrier components were obtained namely: Central government bureaucracy; Minimal control of MMDAs; Political influence; MMDA project funding; Lack of capacity of MMDAs; and Political interference. The six (6) principal components and their associated variables are shown in Table 4.

\subsubsection{Discussion of Bureaucratic Barriers Impeding Infrastructure Delivery at the MMDAs \\ Component 1: Central Government Bureaucracy}

The principal component accounts for 17.077 per cent of the total variance

Table 2. Kendall's Coefficient of Concordance

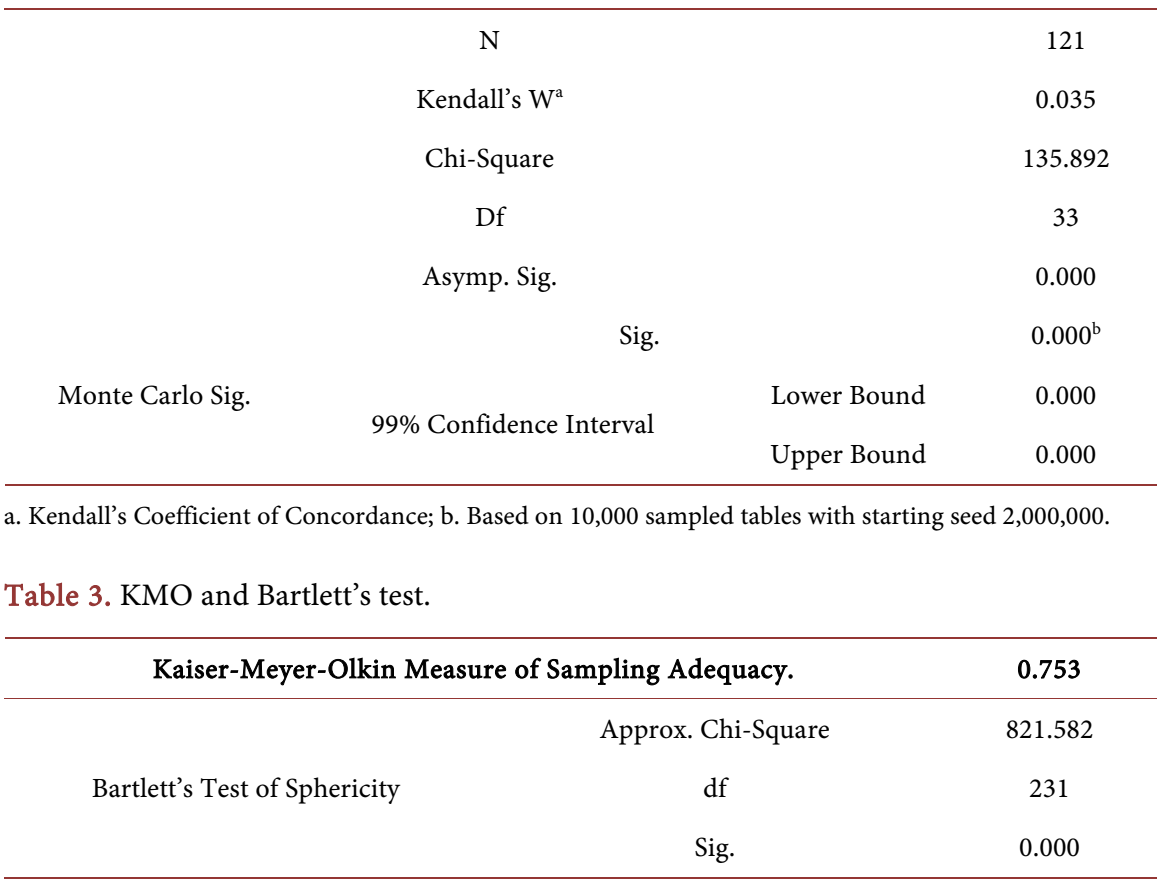


Table 4. Extracted variables and their attributes.

\begin{tabular}{|c|c|c|c|c|}
\hline Bureaucratic Factors & Loadings & Eigenvalue & $\begin{array}{c}\% \text { of Variance } \\
\text { explained }\end{array}$ & $\begin{array}{c}\text { Cumulative \% } \\
\text { Variance explained }\end{array}$ \\
\hline Component 1: Central Government Bureaucracy & & 3.757 & 17.077 & 17.077 \\
\hline Central control of infrastructure procurement delaying construction projects & 0.695 & & & \\
\hline Lack of political commitment to decentralised infrastructure delivery & 0.577 & & & \\
\hline Lack of transparency in infrastructure project selection & 0.724 & & & \\
\hline Corruption in infrastructure procurement & 0.577 & & & \\
\hline Component 2: Minimal Control of MMDAs & & 3.002 & 13.647 & 30.725 \\
\hline Imposition of decisions & 0.751 & & & \\
\hline Slow implementation of decentralisation reforms & 0.792 & & & \\
\hline Regional controls & 0.641 & & & \\
\hline Component 3: Political Influence & & 1.798 & 8.171 & 38.896 \\
\hline Political elite influence & 0.685 & & & \\
\hline Project location selection & 0.575 & & & \\
\hline Regime change & 0.750 & & & \\
\hline Manipulation of stakeholders & 0.709 & & & \\
\hline Use of inefficient political contractors for infrastructural project delivery & 0.709 & & & \\
\hline Line ministries' resistance to decentralisation & 0.493 & & & \\
\hline Component 4: MMDA Project Funding & & 1.739 & 7.903 & 46.799 \\
\hline Slow disbursement of project funding & 0.717 & & & \\
\hline Inadequate project financing & 0.550 & & & \\
\hline Complicated system of financial transfers to local governments & 0.706 & & & \\
\hline Component 5: Lack of capacity of MMDAs & & 1.654 & 7.517 & 54.315 \\
\hline Poor coordination within the MMDAs & 0.615 & & & \\
\hline Lack of involvement of MMDAs in project selection & 0.686 & & & \\
\hline Inadequate control on tax bases for infrastructure delivery & 0.550 & & & \\
\hline Lack of stakeholders' consultation on infrastructure provision policies & 0.683 & & & \\
\hline Component 6: Political Interference & & 1.269 & 5.770 & 60.085 \\
\hline Control of appointments or promotions & 0.676 & & & \\
\hline Interference with legal mandate of MMDAs by MDAs & 0.835 & & & \\
\hline
\end{tabular}

and contains four specific variables (Table 4). The bureaucratic factors making up this component are Central control of infrastructure procurement delaying construction projects, Lack of political commitment to decentralised infrastructure delivery, Lack of transparency in infrastructure project selection, and Corruption in infrastructure procurement. The central government controls most of the activities of the MMDAs almost making them ineffective. According to Amoako-Asiedu and Domfeh [8], the central government's inability to devolve completely authority to the local governments to operate fully makes the deli- 
very of decentralised infrastructure difficult. Local governments, being to a large extent established by the central government, are hence not immune from central control [8] [53]. Article 240 of the 1992 Constitution of Ghana prescribes a devolved form of decentralisation where there is a transfer of authority for decision-making, a sound financial base with adequate and reliable sources of revenue, and management from the central government to the local governments. However, the central government still performs many functions that should be moved to the district level and controls the majority of regional and district financial resources [8]. Award of contracts, recruitment and payment of staff, payment of contractors at the MMDAs, are examples of what is done by the central government instead of the MMDAs. Moreover, the provision of decentralised infrastructure is greatly affected by the lack of political commitment of central government agencies to the implementation of major reforms to ensure effective delivery of infrastructure by the MMDAs [17]. In Ghana, the central government agencies mandated to provide decentralised infrastructure include Ghana Education Trust Fund (GETFund) [54], Funds Procurement and Monitoring Unit of Ministry of Education [55], Ghana Road Fund [56], and many others. These government agencies do not have decentralised offices at the MMDAs, thereby creating many bureaucratic bottlenecks for the provision of the decentralised infrastructure. According to the National Association of Local Governments of Ghana (NALAG) [57], the implementation of fiscal decentralisation has been ineffective due to limited central government commitment. Corruption is another factor that adversely impacts the delivery of infrastructure at the MMDAs [14]. Brierley [15] reinforces this assertion by stating that the engagement of local politicians and civil servants in corruption in infrastructure procurement militates against the delivery of local public infrastructure. In view of the lack of commitment of central government agencies to the Decentralisation of infrastructure delivery, attempts to access these infrastructures at the MMDAs lead to bureaucratic processes which have always given birth to corruption. According to Williams [58], one-third of local infrastructure projects in Ghana stand unfinished as a result of corrupt practices in the contracting process.

\section{Component 2: Minimal Control of MMDAs}

The principal component accounts for 13.647 per cent of the total variance and contains three specific variables (Table 4). The bureaucratic factors making up this component are Imposition of decisions, Slow implementation of decentralisation reforms, and Regional controls. Local governments are unable to make important decisions independently because many legal provisions make them dependent on the central government [11]. Recruitment of qualified staff for MMDAs is done by the central government through the Public Services Commission. The MMDAs, therefore, do not have control over the staff to provide the needed services of MMDAs. Because the majority of the funding for MMDAs infrastructure projects is from the central government, the central gov- 
ernment often imposes upon the MMDAs major infrastructure project decisions including the types of projects to be executed. The decisions about the use and management of the central government transfers have been usurped by the central government so that the MMDAs remain objects of ridicule which lack the necessary finances to implement their decisions [8]. The MMDAs lack the authority to make decisions about expenditures [9]. In recent years, decentralisation reforms in Ghana have taken huge strides. However, there is still the challenge of slow implementation of decentralisation policies and action plans which can be attributed to the inadequate budgetary allocations to local governments in Ghana [57].

\section{Component 3: Political Influence}

The principal component accounts for 8.171 per cent of the total variance and contains six specific variables (Table 4). The bureaucratic factors making up this component are; Political elite influence, Project location selection, Regime change, Manipulation of stakeholders, Use of inefficient political contractors for infrastructure project delivery, and Line ministries' resistance to decentralisation. The MMDAs are usually under political influences that impede their ability to effectively deliver infrastructure, identifiable in many situations. Politicians influence the centralised agencies of Government in the project location, award contracts to contractors, suppliers and service providers to sympathizers of the ruling Government. This influence often begets poor performance on the part of the contractors who, in most cases, are not competent enough to execute these projects [13]. The needed community, therefore, hardly receives the infrastructure as incompetent suppliers, contractors and consultants are awarded the contracts. The situation worsens when there is a change in government (i.e. change in the political power from one party that rules the country to another); infrastructure is provided at the MMDAs in support of the new government. There is a lack of equitable distribution of the projects to the MMDAs. Also, new governments tend to abandon ongoing projects initiated by previous governments to start new ones resulting in inefficiencies in the delivery of infrastructure projects [37]. Furthermore, decentralisation initiatives are often met with heavy bureaucratic or line ministries' resistance. This is usually due to the unwillingness of these line ministries to accept lesser roles in a decentralised system of governance [59]. The delivery of infrastructure at the MMDAs is thereby impeded by the resistance of line ministries to decentralisation.

\section{Component 4: MMDA Project Funding}

The principal component accounts for 7.903 per cent of the total variance and contains three specific variables (Table 4). The bureaucratic factors making up this component are; Slow disbursement of project funding, inadequate project financing, and complicated system of financial transfers to local government. For the MMDAs to carry out their responsibility effectively, they need to have a sufficient level of revenues raised locally and or transferred from the central government or other sources. This process of distribution of public finance and 
responsibilities to the various levels of government is usually referred to as fiscal decentralisation. Fiscal decentralisation aims to strengthen the finances of local governments and thus their capacity to provide public goods and services [9]. The Local Government Service [60] asserted that the major challenge which hampered the smooth delivery of infrastructure at the local level was delay in the release of funds from the central government. The majority of the funding for MMDA projects is from the central government; however, the MMDAs face the challenge of slow release of project funds inhibiting their delivery of infrastructure. According to Article 252 of the 1992 Constitution of the Republic of Ghana, the District Assemblies Common Fund (DACF) has been set up to provide monies to the MMDAs. Currently, the DACF is set as five (5) per cent of the Consolidated Fund of the Country. The amount is, however, inadequate and is released to the MMDAs as and when the central government decides. It is under the control of the central government. In addition, the receipt of funds from central government transfers is highly unpredictable and inconsistent and not very frequent [61]. The financing of infrastructure projects is a major problem confronting MMDAs in Ghana [54]. Besides the inadequate funds from the DACF, the MMDAs are to levy the people within their localities in order to generate internal funding. The internally generated fund is subject to bye-laws to be gazetted by the central government. The MMDAs are unable to fix fees adequate for their operations. The funds for contracts awarded by the centralised agencies are also controlled by the agencies as well as the release of funds for payments of infrastructure provided at the local level [60]. The procurement of infrastructure projects at the MMDAs is bedevilled by the non-availability or inadequacy of project funding and the untimely release or slow disbursement of funds [62]. This further undermines the ability of the MMDAs to effectively plan and budget for infrastructure projects. Infrastructure financing at the MMDAs faces a highly complex system of financial transfers from central government to local government.

\section{Component 5: Lack of Capacity of MMDAs}

The principal component accounts for 7.517 per cent of the total variance and contains four specific variables (Table 4). The bureaucratic factors making up this component are Poor coordination within the MMDAs, Lack of involvement of MMDAs in project selection, inadequate control on tax bases for infrastructure delivery, and Lack of consultation or involvement of stakeholders in infrastructure delivery policies. One of the major factors that impede the effective delivery of infrastructure at the MMDAs is poor coordination within the MMDAs [38]. The lack of effective coordination between levels of government has created problems of duplication or gaps in the provision of synergy in the utilisation of resources and has led to major delays for even those projects where funding was available. According to the Local Governance Act, 2016 (Act 936) [63], Regional Coordinating Council (RCC) has the function of coordinating the activities of the MMDAs within the respective Regions in Ghana. The lack of effective coor- 
dination creates bureaucratic bottlenecks in reaching out to the central government for infrastructure supports. Also, the non-involvement or lack of consultation of stakeholders on infrastructure delivery policies is a challenge to the effective delivery of infrastructure at the MMDAs [64]. The activities of the centralised agencies in providing infrastructure at the local levels do not involve the stakeholders of the infrastructure including beneficiaries, users, traditional authorities and community leaders, among others. The governments prepare estimates for projects for their revenue and expenditure with or without proper involvement and consultation with the people for whom the exercise is being carried out to know their needs, problems and potentials [65]. There is also the lack of involvement of MMDAs in the selection of infrastructure projects. Decentralised infrastructure delivery may be funded through taxes. However, according to Ankamah [66], tax collectors often have insufficient information on the collection of taxes for infrastructural works in the country. Poor compliance and weak enforcement mean that the level of local taxes collected is generally low. This has made local governments heavily dependent on central government funding which is not adequate to execute meaningful projects thereby causing delays [67].

\section{Component 6: Political Interference}

The principal component accounts for 5.770 per cent of the total variance and contains two specific variables (Table 4). The bureaucratic factors making up this component are Control of appointments or promotions and Interference with the legal mandate of MMDAs. Politicians have more often than not used the slogan of decentralisation as rhetoric to strengthen their power base rather than improving the quality of governance in the government. The recruitment of staff at the MMDAs is often politicised, where Mohammed [68] argued that staffing with political appointees usually leads to low performance. Political appointees perform systematically lower than non-partisan appointees from civil service [69]. Moreover, the recruitment of personnel under the MMDAs is centralized in the sense that the MMDAs are granted no autonomy to recruit and cater for their staffing needs which would have been more efficient. This increases bureaucracy and slows down infrastructure development in the country [70] (Figure 1).

\section{Conclusion, Implications and Recommendations}

This study assessed the bureaucratic factors impeding the delivery of infrastructure at the MMDAs in Ghana. It adopted the quantitative research approach. Data for the study was obtained from 121 professionals in the MMDAs who were purposively sampled from 36 MMDAs in the Greater Accra and Ashanti Regions of Ghana. The findings of the study revealed six (6) major components of the bureaucratic factors that impede the delivery of infrastructure at the MMDAs in Ghana. They are Central government bureaucracy, Minimal control of MMDAs, Political influence, MMDA project funding, Lack of capacity of 


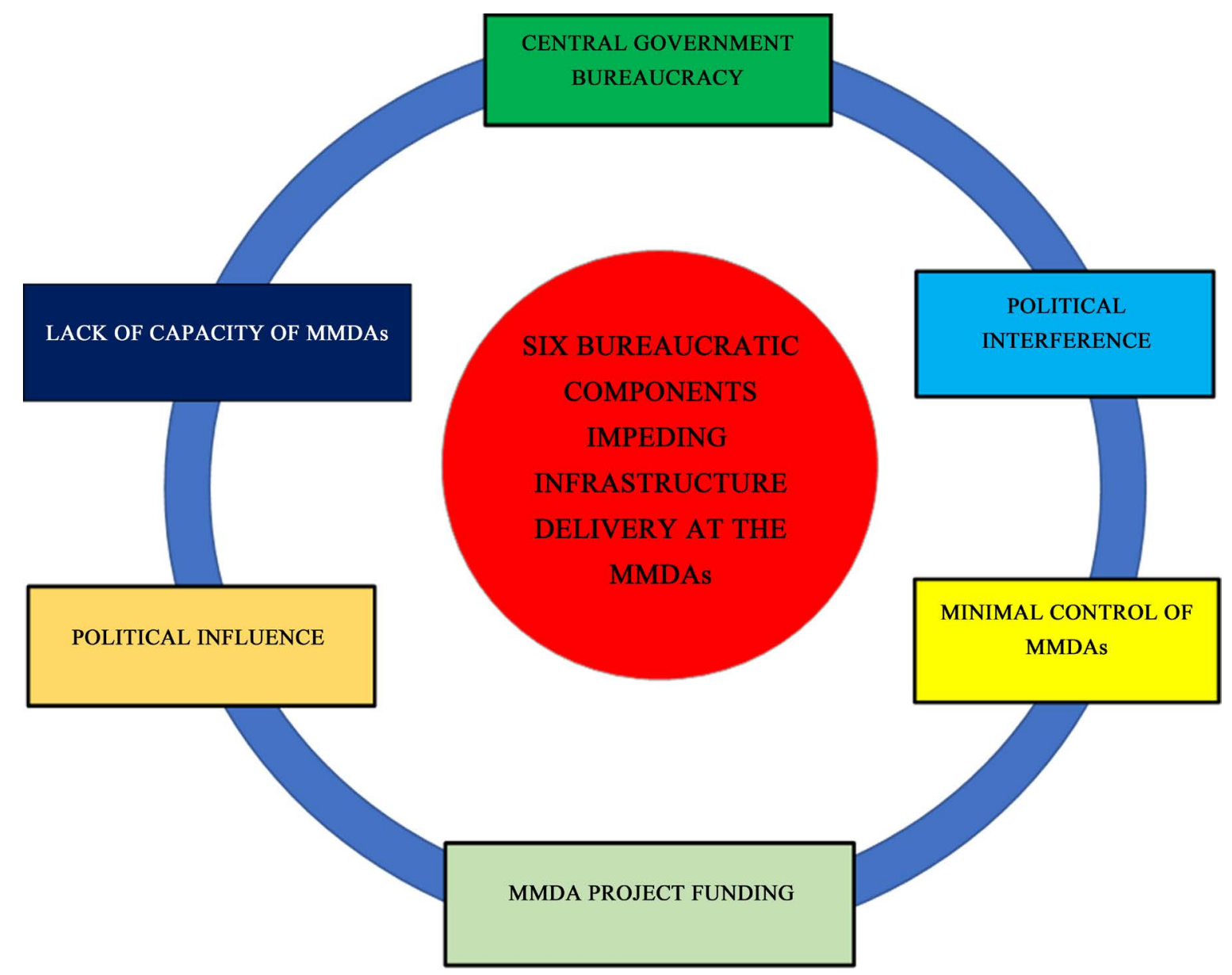

Figure 1. Bureaucratic barriers impeding infrastructure delivery at the MMDAs.

MMDAs, and Political interference. The study identified that bureaucratic control mechanisms over the responsibilities of the MMDAs seriously impede their ability to deliver infrastructure and renders them ineffective. Again, the MMDAs are unable to exercise autonomy in decision-making as a result of political influences. These bureaucratic factors, coupled with others, act as impediments to the effective delivery of infrastructure at the MMDAs.

This paper contributes to efforts to improving infrastructure development in Ghana. The findings of the study would inform key decentralised infrastructure delivery stakeholders of the bureaucratic impediments to the delivery of infrastructure at the MMDAs. The findings of the study could also prove useful to policymakers to develop and implement decentralised infrastructure-related policies that would remove the bureaucratic obstacles in the delivery of infrastructure at the MMDAs. This would increase the capacity of the MMDAs to effectively provide infrastructure for their localities.

The following recommendations are thus made by this study:

- The central government needs to maintain some control over the operations of the MMDAs in Ghana; however, to ensure effective delivery of infrastructure at the MMDAs, this control should not, in any way, interfere with their 
delivery of infrastructure.

- The MMDAs must also be granted the autonomy to take major decisions on infrastructure projects devoid of political interferences.

- The MMDAs should be able to define and have full access to their tax bases in order to minimize their heavy reliance on central government transfers and the controls that come therewith.

- A change in government should not affect any ongoing projects within the MMDAs.

- The MMDAs should be adequately resourced and provided with the needed capacity to enable them effectively deliver decentralised infrastructure.

- Adequate decentralised structures need to be established to eliminate the bureaucratic obstacles in the delivery of infrastructure at the MMDAs.

\section{Conflicts of Interest}

The authors declare no conflicts of interest regarding the publication of this paper.

\section{References}

[1] Albehadili, A.F.S. and Hai, L.X. (2018) Impacts of Fiscal Decentralisation and Economic Growth: A Meta-Analysis Approach. International Journal of Management Science and Business Administration, 4, 34-43. https://doi.org/10.18775/ijmsba.1849-5664-5419.2014.45.1004

[2] Bardhan, P. (2002) Decentralisation of Governance and Development. Journal of Economic Perspectives, 16, 185-205. https://doi.org/10.1257/089533002320951037

[3] World Bank (2001) Global Development Finance: Building Coalition for Effective Development Finance. Washington DC.

[4] Olaseni, M. and Alade, W. (2012) Vision 20:2020 and the Challenges of Infrastructural Development in Nigeria. Journal of Sustainable Development, 5, 63-76. https://doi.org/10.5539/jsd.v5n2p63

[5] Organisation for Economic Co-Operation and Development/African Center for Economic Transformation (OECD/ACET) (2020) Quality Infrastructure in 21st Century Africa: Prioritising, Accelerating and Scaling Up in the Context of Pida (2021-30).

[6] Hossain, M.A. (2004) Administrative Decentralisation: A Framework for Discussion and Its Practices in Bangladesh. University of Rajshahi, Department of Public Administration, Rajshani.

[7] Lawal, T. (2014) Local Government and Rural Infrastructural Delivery in Nigeria. International Journal of Academic Research in Business and Social Sciences, 4, 139. https://doi.org/10.6007/IJARBSS/v4-i4/771

[8] Amoako-Asiedu, E. and Domfeh, K.A. (2016) The Challenges of Central Government Fiscal and Financial Policies on Local Government Programmes in Ghana. International Journal of African and Asian Studies, 26, 32-40.

[9] Yeboah, E.N. and Andrew, M. (2020) Challenges Faced by Metropolitan, Municipal, and District Assemblies (MMDAs) in Internal Revenue Mobilization in Ghana. International Journal of Asian Social Science, 10, 68-80. https://doi.org/10.18488/journal.1.2020.101.68.80 
[10] Yeboah-Assiamah, E. (2016) Power to the People! How Far Has the Power Gone to the People? A Qualitative Assessment of Decentralisation Practice in Ghana. Journal of Asian and African Studies, 51, 683-699. https://doi.org/10.1177/0021909614555349

[11] Ringo, C.J. and Mollel, H.A. (2014) Making Decentralisation Promote Empowerment of the Local People: Tanzanian Experience. International Journal of Business and Social Science, 5, 175-180.

[12] Damoah, I.S. and Kumi, D. (2018) Causes of Government Construction Projects Failure in an Emerging Economy: Evidence from Ghana. International Journal of Managing Projects in Business, 11, 558-582. https://doi.org/10.1108/IJMPB-04-2017-0042

[13] Kissi, E., Mohammed, S.A. and Owusu-Diatuo, K.J. (2018) Challenges Facing Public Works Departments in Construction Project Delivery within Metropolitan Municipal and District Assemblies in Ghana. UDS International Journal of Development, 5, 129-143.

[14] Ankrah, N., Mante, J. and Ndekugri, I. (2015) The Challenges of Infrastructure Procurement in Emerging Economies and Implications for Economic Development: A Case of Ghana. In: Real Estate, Construction and Economic Development in Emerging Market Economies, Routledge, London, 174.

[15] Brierley, S. (2018) Procurement Mismanagement and the Politicization of Bureaucratic Transfers in Ghana. International Growth Centre (IGC), London, Policy Brief (33304).

[16] Ngware, S. and Haule, M. (1993) The Forgotten Level: Village Government in Tanzania. Hamburg African Studies, Dar es Salaam.

[17] Ministry of Local Government and Rural Development (MLGRD) (2010) Decentralisation Policy Framework: Theme, Accelerating Decentralisation and Local Governance for National Development. Ministry of Local Government and Rural Development.

[18] Katsiaouni, O. (2003) Decentralisation and Poverty Reduction: Do It Work? The Workshop on Linking Decentralised Governance and Human Development (UNDP, UN$C D F, W B I$, and $U N-D E S A)$, Mexico City, Interregional Adviser, UNDESA, 3 November 2003.

[19] Misuraca, G. (2002) Decentralisation and Local Governance: Benefits and Limits. On Decentralisation and Privatization.

[20] Ahwoi, K. (2010) Local Government and Decentralisation in Ghana. Unimax Macmillan Ltd., Accra.

[21] Hoedoafia, M.A. (2019) Private Sector Development in Ghana: An Overview. MPRA Paper 96732. https://doi.org/10.2139/ssrn.3569529

[22] Magdalene, A. (2013) Ghana Steps Up Infrastructure Investment. World Finance.

[23] Karimi, S., Zhakfar, Z. and Sarwary, M.I. (2020) Study of Excessive Bureaucracy in Construction Projects-Causes of Low Level of Competition and Lengthy Tendering Process: A Case Study of Afghanistan. International Journal of Engineering and Advanced Technology, 10, 66-73. https://doi.org/10.35940/ijeat.A1707.1010120

[24] Kaufman, H. (1977) Red Tape, Its Origins, Uses, and Abuses. Brookings Institution, Washington DC.

[25] Al Qahtani, K.M. (2013) Investigating the Impact of Bureaucratic Factors on Government Organisational Performance in the Kingdom of Bahrain: A Multiple Case Study Approach. Doctoral Dissertation, Brunel University, London. 
[26] Asante, L.A. and Helbrecht, I. (2020) The Urban Dimension of Chinese Infrastructure Finance in Africa: A Case of the Kotokuraba Market Project, Cape Coast, Ghana. Journal of Urban Affairs, 42, 1278-1298. https://doi.org/10.1080/07352166.2019.1629819

[27] Puopiel, F. and Chimsi, M. (2015) Mobilizing Internally Generated Funds to Finance Development Projects in Ghana's Northern Region. Commonwealth Journal of Local Governance, 18, 147-160. https://doi.org/10.5130/cjlg.v0i18.4848

[28] Adu-Gyamfi, E. (2014.) Effective Revenue Mobilization by District Assemblies: A Case Study of Upper Denkyira East Municipal Assembly of Ghana. Public Policy and Administration Review, 2, 97-122.

[29] Dzansi, J. (2016) Institutions Matter in Infrastructure Delivery in Ghana.

[30] Bahl, R. and Bird, R. (2013) Decentralisation and Infrastructure in Developing Countries: Reconciling Principles and Practice (No. 16). University of Toronto, Institute on Municipal Finance and Governance, Toronto.

[31] Bahl, R. and Bird, R.M. (2014) Decentralisation and Infrastructure: Principles and Practice. International Centre for Public Policy Working Paper Series, at AYSPS, GSU, (paper 1408).

[32] Togba, P.N. (2014) Decentralisation and Service Delivery: A Comparative Case Study of the Health and Social Welfare Departments in Liberia. Doctoral Dissertation, University of Ghana, Accra.

[33] Crook, R.C. and Sverrisson, A.S. (2001) Decentralisation and Poverty Alleviation in Developing Countries: A Comparative Analysis or, Is West Bengal Unique?

[34] Bhattacharya, A., Meltzer, J.P., Oppenheim, J., Qureshi, Z. and Stern, N. (2016) Delivering on Sustainable Infrastructure for Better Development and a Better Climate. Global Economy and Development, The Brookings Institution, Washington DC.

[35] Anabah, J.W. (2015) Challenges to the Public Procurement Act Implementation within the Municipal and District Assemblies in the Upper East Region of Ghana. Doctoral Dissertation.

[36] Asante, J.A. (2014) Financial Distress Related Causes of Project Delays in the Ghanaian Construction Industry. Doctoral Dissertation.

[37] Damoah, I.S., Mouzughi, Y. and Kumi, D.K. (2020) The Effects of Government Construction Projects Abandonment: Stakeholders' Perspective. International Journal of Construction Management, 20, 462-479. https://doi.org/10.1080/15623599.2018.1486172

[38] Bertucci, G. (2003) Decentralisation and Poverty Reduction: Africa and Asia Experience; Economic and Social. Dakar.

[39] East Asia Forum (2015) Indonesia’s Infrastructure Progress Is Thwarted by Its Decentralised Structure.

[40] Van Weele (2000) Purchasing and Supply Management. Thomson Press, Canton.

[41] Creswell, J.W. (2014) Research Design: Qualitative, Quantitative, and Mixed Methods Approach. 4th Edition, Sage, Los Angeles.

[42] Ayyash, M.M., Ahmad, K., Singh, D., Ayyash, M.M., Ahmad, K. and Singh, D. (2011) A Questionnaire Approach for User Trust Adoption in Palestinian E-Government Initiative. American Journal of Applied Sciences, 8, 1202-1208.

https://doi.org/10.3844/ajassp.2011.1202.1208

[43] Sawe, B.E. (2018) Biggest Cities in Ghana. WorldAtlas.

[44] Works Department Operational Manual (2018) Local Government Service (LGS) Es- 
tablishment, Operationalization, and Management for the Metropolitan, Municipal, and District Assemblies (MMDAs).

[45] Greener, S. (2008) Business Research Methods. Ventus Publishing, Frederiksberg.

[46] Ahadzie, D.K. (2007) A Model for Predicting the Performance of Project Managers in Mass House Building Projects in Ghana. PhD Thesis, School of Engineering and the Built Environment, University of Wolverhampton, Wolverhampton.

[47] Kissi, E., Boateng, E.B., Adjei-Kumi, T. and Badu, E. (2017) Principal Component Analysis of Challenges Facing the Implementation of Value Engineering in Public Projects in Developing Countries. International Journal of Construction Management, 17, 142-150. https://doi.org/10.1080/15623599.2016.1233088

[48] Cheng, E.W. and Li, H. (2002) Construction Partnering Process and Associated Critical Success Factors: Quantitative Investigation. Journal of Management in Engineering, 18, 194-202. https://doi.org/10.1061/(ASCE)0742-597X(2002)18:4(194)

[49] Mao, C., Shen, Q., Pan, W. and Ye, K. (2015) Major Barriers to Off-Site Construction: The Developer's Perspective in China. Journal of Management in Engineering, 31, Article ID: 04014043. https://doi.org/10.1061/(ASCE)ME.1943-5479.0000246

[50] Afful, A.E. (2019) Principles Defining Social Sustainability within the Ghanaian Construction Industry. MPhil Thesis, The Department of Construction Technology and Management, College of Art and Built Environment, Kumasi.

[51] Field, A. (2005) Factor Analysis Using SPSS. Retrieved March, Vol. 17, No. 2019, 63-71.

[52] Norusis, M.J. (2003) SPSS 12.0 Statistical Procedures Companion. Prentice Hall, Upper Saddle River.

[53] Mohan, G. (1996) Adjustment and Decentralization in Ghana: A Case of Diminished Sovereignty. Political Geography, 15, 75-94. https://doi.org/10.1016/0962-6298(95)00009-7

[54] Badu, E., Edwards, D.J., Owusu-Manu, D. and Brown, D.M. (2012) Barriers to the Implementation of Innovative Financing (IF) of Infrastructure. Journal of Financial Management of Property and Construction, 17, 253-273. https://doi.org/10.1108/13664381211274362

[55] Public Procurement Authority (PPA) (2019) Expression of Interest-Details. The Republic of Ghana.

[56] Millennium Challenge Cooperation (2020) Improving Roads to Reduce Transportation Costs in Ghana. Evaluation Brief, September.

[57] National Association of Local Governments of Ghana (NALAG) (2020) Integration of National Association of Local Authorities of Ghana in the European Cooperation Programming Process 2021-2027. Compendium of Key Reference Documents.

[58] Williams, M. (2015) Bricks-and-Mortar Institutions Matter Project Delivery and Unfinished Infrastructure in Ghana's Local Governments. International Growth Centre (IGC), Policy Brief (89105).

[59] Martinez-Vazquez, J. and Vaillancourt, F. (2011) Obstacles to Decentralisation: Lessons from the Developing World. Decentralisation in Developing Countries: Global Perspectives on the Obstacles to Fiscal Devolution, Issue September, 1-13.

[60] Local Government Service (2014) Annual Progress Report. Republic of Ghana.

[61] Adamtey, R., Sarpong, E.T. and Obeng, G. (2020) A Study towards Deepening Fiscal Decentralisation for Effective Local Service delivery in Ghana. Final Research Report, Good Governance Africa.

[62] Adaliwor, I.W. (2017) Exploring the Risk Management Practices of the Metropoli- 
tan, Municipal, and District Assemblies in Construction Project Delivery. Doctoral Dissertation.

[63] Local Governance Act (2016) (Act 936) Ghana Publishing Company Limited, Assembly Press, Accra.

[64] Fosu, M.A. (2012) An Evaluation of Effectiveness of Revenue Mobilization Strategies of Metropolitan, Municipal and District Assemblies (MMDAs) in Ghana: A Case Study of Kumasi Metropolitan Assembly (KMA). Doctoral Dissertation.

[65] Lawal, S. (2000) Local Government Administration in Nigeria: A Practical Approach. Theory and Practice of Local Government.

[66] Ankamah, S.S. (2012) The Politics of Fiscal Decentralisation in Ghana: An Overview of The Fundamentals. Public Administration Research, 1, 33. https://doi.org/10.5539/par.v1n1p33

[67] Odoh, A. (2004) An Assessment of the Operation of Local Governments under Civil Democracy in Nigeria (1999-2003). The Journal of Administration, 22, 45.

[68] Mohammed, A.W.A. (2018) Politics in Decentralisation: The Appointment of Metropolitan, Municipal and District Chief Executives (MMDCEs) in Ghana. Advances in Social Sciences Research Journal, 5, 570-588. https://doi.org/10.14738/assrj.512.4675

[69] Lewis, D.E. (2007) Testing Pendleton's Premise: Do Political Appointees Make Worse Bureaucrats? The Journal of Politics, 69, 1073-1088.

https://doi.org/10.1111/j.1468-2508.2007.00608.x

[70] Sulemana, M. (2009) Understanding the Causes and Impacts of Conflicts in the Northern Region of Ghana. The Ghana Policy Journal, 3, 110-139. 